\title{
技術論文
}

\section{グリセミック・インデックスの近赤外分光法を用いた 非侵襲血糖測定の評価}

\author{
百瀬晶子 ${ }^{1 *}$, 池羽田晶文 ${ }^{2}$, 上平安紘 ${ }^{2}$, 三浦理代 $^{1}$ \\ 1 女子栄養大学 \\ ${ }^{2}$ 国立研究開発法人 農業·食品産業技術総合研究機構 食品研究部門
}

\begin{abstract}
Comparative Study on Self-Monitoring of Blood Glucose and Non-invasive Blood Glucose Sensor
Using Short-wavelength Near-infrared Spectroscopy in Glycemic Index Determination
\end{abstract}

Akiko Momose $^{1 *}$, Akifumi Ikehata ${ }^{2}$, Yasuhiro Uwadaira ${ }^{2}$ and Masayo Miura ${ }^{1}$

${ }^{1}$ Kagawa Nutrition University, 3-9-21 Chiyoda, Sakado, Saitama 350-0288

${ }^{2}$ Food Research Institute, NARO, 2-1-12 Kannondai, Tsukuba, Ibaraki 305-8642

\begin{abstract}
Postprandial hyperglycaemia control is important to prevent or treat diabetes, and also to lower the risk of complications. The glycemic index (GI) is one of the indices for controlling postprandial blood glucose levels. Both blood glucose control in diabetic patients and GI determinations require frequent blood samplings by self-monitoring of blood glucose, which is a major burden for patients and subjects. Thus, a new non-invasive method for measuring blood glucose is highly desirable. We examined the GI for five kinds of combination meals such as rice with vegetables (cabbage, komatsuna, tomato, soybean, and nagaimo) using white rice as a reference food. In addition, the non-invasive blood glucose determination using near-infrared (NIR) spectroscopy was studied as part of the GI determination. Spectra in the short-wavelength NIR region from 700 to $1050 \mathrm{~nm}$ were measured on the palm of the hand. For each 2-h GI test, the blood glucose level was estimated from the spectral intensity by using simple linear regression analysis. Our results indicate that the GI for all combination meals was below 100 as determined by the reference food, and the blood glucose value was accurately estimated using the NIR technique during each GI test. (Received Dec. 4, 2015 ; Accepted Jul. 27, 2016)
\end{abstract}

Keywords : glycemic index, moderating postprandial blood glucose level, blood glucose, non-invasive, near-infrared spectroscopy キーワード : グリセミック・インデックス，食後血糖上昇抑制，血糖值，非侵襲，近赤外分光法

食後高血糖は糖尿病の発症や治療の増悪, 循環器疾患発 症のリスクファクターであることが報告されており ${ }^{1)}$, 国 際糖尿病連合（IDF/2007 年）の食後血糖值の管理に関す るガイドラインでも, その重要性が強調されている6).

食品の食後血糖上昇の程度を表す指標として, 1981 年に Jenkins らにより Glycemic Index（GI）が提唱され7)，GIの 導入は糖尿病管理に有益であるとされている6! こ これまで の GI に関する検討は欧米の食習慣に適応する食品が中心 であり，我が国において GI を活用した食後血糖管理の普 及が進まない要因の一つとなっている。近年の日本人の食 に対する価值観は多様化する一方, 国民健康栄養調査 (H25）の生活習慣調査結果 ${ }^{8)}$ によると，「主要な食品の摂 取頻度」において総人数の $69.4 \%$ が毎日 2 回以上「ごはん」 を摂取していると回答しており，米飯主体の食習慣は現在 でも日本の食文化に根づいているといえる。よって，日本
型食生活に活用できるような米飯を基準食とした GI の検 討が望まれている。これまでに，杉山らは「ごはん食」の 食べ方について GI の観点から検討を行っており, 高 GIで ある米飯と他の食品との食べ合わせ等に関する GI データ を蓄積している9 . また, 多くの食品を組み合わせて摂取す る日本食に対しては食品毎に評価したGIの適応が難し く, 今後複数の食品を一度に「食事の形態」で摂取し GI を 評価することが課題となる，以上のことから，本研究では 日本型食生活に根ざした食事の形態における GI 検証の先 駆けとして，主食の米飯に副菜としての摂取量に配慮した 検査食品一品を組み合わせた際の GI の変化について検討 を試みた。また，副菜として摂取した食品中の成分と GI との関連について検討するため, GIに影響を及ぼすこと が示唆される食品機能性成分分析も合わせて実施した。

一方，糖尿病患者の血糖管理や GI 測定において用いら 
れる血糖自己測定 (SMBG) は，採血を伴う上に測定回数 が頻回であることから，より安全で負担の伴わない方法が 求められている。これまでに，採血を必要としない非侵襲 的な血糖測定法として, 光の透過性の高い短波長領域 （700～1 100 nm）を用いた近赤外分光法による検討が重ね られてきた。しかし，個人差，日間差等の影響から不特定 多数のヒトに適用可能な汎用型測定法の開発に成功した例 はなく，また，個人専用測定法においても良好な検量モデ ルが構築できる場合とそうでない場合が存在し, 未だ実用 化には至っていない(10) 13). GI 測定では試験食摂取後 2 時 間までの非侵襲測定を実現することが期待されるが，この 目的に特化して開発された非侵襲血糖測定法はない.今回 前述の GI 測定のために実施した 400 回近い試験食負荷試 験において, SMBG と合わせて生体の近赤外スペクトルを 測定し, 負荷試験中の両者の相関関係について解析を行い, 非侵襲血糖測定技術の GI 測定への応用可能性についても 検証を行った.

\section{実 験 方 法}

\section{GI 測定}

GI 測定は日本 GI 研究会のプロトコール に準拠して 行った。香川栄養学園倫理審査委員会より承認を受け, 対 象者にヘルシンキ宣言に則ったインフォームドコンセント を行い了承を得た。

(1) 対象者

対象者は健常女性 36 名（年齢 $20.7 \pm 0.5$ 歳, BMI $20.3 \pm$ 1.8）であり，日本糖尿病学会による糖代謝異常の判定基準 に従い, $75 \mathrm{~g}$ 経ロブドウ糖負荷試験（oral glucose tolerance test：OGTT）により糖代謝異常が認められないこと を確認した（表 1 ).

（2）試験食

基準食は包装米飯（糖質 $50 \mathrm{~g}$ 相当量, サトウのごはん,
サトウ食品(株)）とし，検査食は基準食と同様の包装米飯 と検査食品一品の組み合わせとした。検査食品には一般に 入手可能な植物性食品 5 種類（こまつな，キャベッ，トマ 卜，だいず，ながいも）を選択した。各試験食の構成食品 および栄養成分組成を表 2 に示した。検査食品の摂取量 は, こまつな, キャベッ, トマトの 3 種類については, 健康 日本 21 (第二次) の 1 日の野菜平均摂取量 $350 \mathrm{~g}$ の目標值 より, その約 $1 / 3$ 量 $(120 \mathrm{~g})$ を 1 食の摂取量とし, $120 \mathrm{~g}$ (生) 相当量に設定した。だいずは糖尿病食事療法のための食品 交換表 (第 7 版 $)^{14)}$, 四群点数法 ${ }^{1516)}$ より, 約 1 点 $(80 \mathrm{kcal})$ 分の摂取量として市販品の栄養成分表示より算出して水煮 $55 \mathrm{~g}$ とした. 尚, 四群点数法では豆類は第 2 群の食品であ り主菜として用いられるが, 一方で副菜としても使用され ることがある。ながいも (生) は, 1 点 $(80 \mathrm{kcal})$ 分の 123 $\mathrm{g}$ (生) を摂取量とすると, 本研究のプロトコールにおい て，米飯とながいもの重量バランスが不釣り合いとなり摂 取困難なため, 食事バランスガイド17) の副菜 $1 \mathrm{SV}$ を参考 に $80 \mathrm{~g}$ (生) に設定した。検査食品は次の様に調製した. こまつな, キャベツは可食部（生） $120 \mathrm{~g}$ 相当量をブランチ ング後, 凍結保存し, 摂取直前に電子レンジ解凍した。 マトは外果皮を除去した可食部 (生) $120 \mathrm{~g}$ 相当量を凍結保

表 1 対象者の概要

\begin{tabular}{lc}
\hline \hline & mean $\pm \mathrm{SD}$ \\
\hline 人数 $(\mathrm{n})$ & 36 \\
性別 & 女性 \\
年齢 $($ 歳 $)$ & $20.7 \pm 0.5$ \\
身長 $(\mathrm{cm})$ & $158.2 \pm 5.2$ \\
体重 $(\mathrm{kg})$ & $50.9 \pm 5.4$ \\
BMI $\left(\mathrm{kg} / \mathrm{m}^{2}\right)$ & $20.3 \pm 1.8$ \\
空腹時血糖值 $(\mathrm{mg} / \mathrm{dL})$ & $82 \pm 9$ \\
$75 \mathrm{~g}$ OGTT 2 時間值 $(\mathrm{mg} / \mathrm{dL})$ & $116 \pm 14$ \\
\hline
\end{tabular}

表 2 試験食の構成食品および栄養成分組成*

\begin{tabular}{|c|c|c|c|c|c|c|c|}
\hline & & 基準食 & $\begin{array}{l}\text { 検査食 } \\
\text { (こまつな) }\end{array}$ & $\begin{array}{l}\text { 検査食 } \\
\text { (キャベッ) }\end{array}$ & $\begin{array}{l}\text { 検査食 } \\
\text { (だいず) }\end{array}$ & $\begin{array}{l}\text { 検査食 } \\
\text { (トマト) }\end{array}$ & $\begin{array}{c}\text { 検査食 } \\
(\text { ながいも) }\end{array}$ \\
\hline 米飯 & (g) & 149 & 146 & 140 & 141 & 135 & 117 \\
\hline 検査食品 & (g) & - & $\begin{array}{c}120 \\
(\text { 可食部/生/相当量) }\end{array}$ & $\begin{array}{c}120 \\
(\text { 可食部/生/相当量) }\end{array}$ & $\begin{array}{c}55 \\
\text { (水煮) }\end{array}$ & $\begin{array}{c}120 \\
(\text { 可食部/生/相当量) }\end{array}$ & $\begin{array}{c}80 \\
\text { (可食部/生/相当) }\end{array}$ \\
\hline ゆかり & $(\mathrm{g})$ & 1 & 1 & 1 & 1 & 1 & 1 \\
\hline 水 & $(\mathrm{mL})$ & 150 & 150 & 150 & 150 & 150 & 150 \\
\hline エネルギー & (kcal) & 221 & 232 & 229 & 289 & 226 & 226 \\
\hline 炭水化物 & (g) & 50.9 & 53.1 & 52.8 & 54.5 & 52.0 & 51.3 \\
\hline たんぱく質 & (g) & 3.2 & 4.9 & 4.0 & 10.0 & 4.0 & 4.4 \\
\hline 脂質 & (g) & 0.0 & 0.1 & 0.2 & 3.8 & 0.2 & 0.2 \\
\hline 糖質 & $(\mathrm{g})$ & 50.4 & 50.0 & 50.1 & 50.0 & 50.0 & 50.0 \\
\hline 食物繊維 & $(\mathrm{g})$ & 0.5 & 3.1 & 2.6 & 4.5 & 2.0 & 1.2 \\
\hline 食塩相当量 & (g) & 0.4 & 0.41 & 0.41 & 0.61 & 0.41 & 0.41 \\
\hline
\end{tabular}

*栄養価計算は市販品は栄養成分表示を参考にし，その他は五訂増補食品成分表より計算した。 


\begin{tabular}{cc}
\hline \multicolumn{2}{c}{ 表 $\mathbf{3}$ 統一タ食の栄養成分組成 } \\
\hline \hline エネルギー $(\mathrm{kcal})$ & 629 \\
炭水化物 $(\mathrm{g})$ & 90.2 \\
たんばく質 $(\mathrm{g})$ & 23.9 \\
脂質 $(\mathrm{g})$ & 17.1 \\
食物繊維 $(\mathrm{g})$ & 6.3 \\
食塩相当量 $(\mathrm{g})$ & 3.2 \\
\hline
\end{tabular}

*エクセル栄養君で計算

存し, 摂取直前に半解凍した，だいずは市販品の水煮 $55 \mathrm{~g}$ を水切りした，ながいもは可食部（生） $80 \mathrm{~g}$ を掑取直前に 棒状にカットした。また, 各検査食は一食が糖質 $50 \mathrm{~g}$ 相当 量となるよう米飯の量を調節した。

(3) GI 測定方法

GI 測定に当たり, 測定前日は過激な運動や暴领暴食, 夜 更かしは避け, 夕食は統一食（表3）を20 時までに摂取し, それ以降は水以外の飲食はしないこととした，測定当日 は, 測定前日から 10 時間以上の絶食後, 午前 9 時までに測 定を開始し, 空腹時血糖をSMBG により測定した. SMBG には，(株)アークレイマーケティングのグルコカード ${ }^{\mathrm{TM}} \mathrm{G}$ ブラック GT-1830を用いた，その後, 基準食または検査食 を水 $150 \mathrm{~mL}$ と共に摂取 (一口の咀嚼回数 30 回程度, 摂取 時間 5 10 分とし, 検査食については米飯と検査食品を一 口ずつ交互に食べ摂取順序も統一) した後, 2 時間 (摂取開 始 $15 ， 30 ， 45 ， 60 ， 90 ， 120$ 分後) の血糖を測定した。対象 者をランダムに 3 グループに分け（1グループ 10 名以上）, グループ毎に摂取する検査食を割り振った。また，各対象 者は基準食の負荷試験を 2 回行った後, 検査食の負荷試験 を2 回行い, 測定は連続しない別の日に行った。目 GI 研究会のプロトコールに従って, 試験食毎に血糖上昇曲線 下面積 (the incremental area under the blood glucose response curve：IAUC）を算出し，その差が $25 \%$ 以内となる 平均值を各対象者の $\mathrm{GI}$ 算出に用いる基準值として採用し た。また, IAUCの差が $25 \%$ 以上の場合は, 再試験を行い $25 \%$ 以内の值を平均して基準值とした。各検査食の GI は, 対象者毎に基準食のIAUC の基準值に対する相対値として 求めた。尚, 標準偏差の 2 倍（2SD）から外れる対象者の 值 (GI) は除外し, 再平均した值を検査食の平均 GI とした。

\section{(4) 統計処理}

GI の值は平均土標準偏差（mean $\pm \mathrm{SD})$ で示した。基準 食に対する各検查食の摂取後 2 時間の最高血糖值および IAUCの比較は, paired $t$-testにて各検査食のデータと同 対象者の基準食のデータとの平均值の差を検定し, 有意差 は $p<0.05$ を統計的に有意と判定した．解析にはSPSS Ver. 19.0 J for Windows（IBM Japan, Ltd.）を使用した。

\section{2. 検査食品の成分分析}

(1) 検查食品

検査食品 5 種類について, 加熱に上る酵素失活後, 凍結

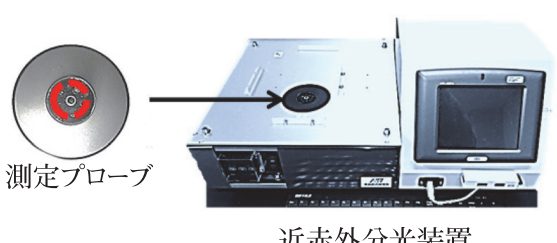

近赤外分光装置

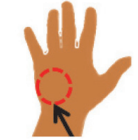

手の平小指球部

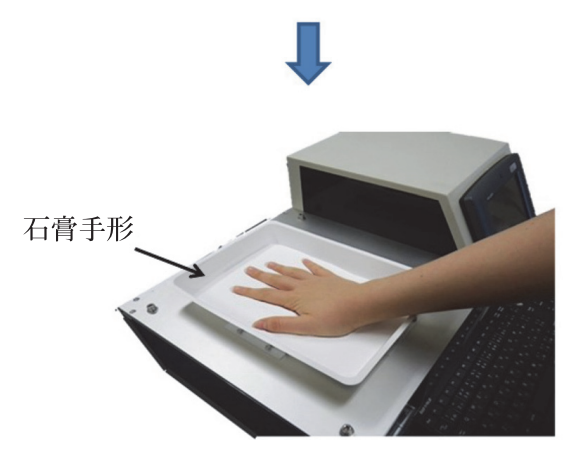

図 1 近赤外分光装置

近赤外分光装置および測定部位，石膏手形を用いた測定の 位置関係を示した図.

乾燥し, 分析に用いた。

(2) 分析項目と方法

i ）総ポリフェノール量：津志田ら ${ }^{18)}$ の方法に準じ, Folin-Ciocalteu 法にて測定した。供試試料 $0.5 \mathrm{~g}$ を採取し, 80 \% メタノール溶液を用いて 30 分攪拌抽出し, 万過した ものを抽出溶液とした，抽出溶液 $1 \mathrm{~mL}$ に 2 倍希釈した Folin-Ciocalteau 試薬 (SIGMA-ALDRICH Corp.) $0.5 \mathrm{~mL}$ と $10 \% \mathrm{Na}_{2} \mathrm{CO}_{3}-1 \mathrm{~N} \mathrm{NaOH}$ 溶液（和光純薬工業(株) $) 5.0 \mathrm{~mL}$ を加え，30 分放置後に遠心分離（3000 rpm，5 分）した上 清の吸光度 $(760 \mathrm{~nm})$ を測定した，標準液をクロロゲン酸 (和光純薬工業(株)）とし, クロロゲン酸当量で算出した.

ii）食物瀻維量：(財)日本食品分析センターへ依頼し, 五訂日本食品標準成分表の分析方法に準拠した方法で分析 した.

\section{3. 近赤外分光法を用いた非侵襲血糖測定法の検討}

測定は生体組織に対して透過性が高く，真皮組織や皮下 組織内の細胞間質液や毛細管血中のグルコース関連の情報 が得られるとされる近赤外短波長領域（700～1 100 nm）を

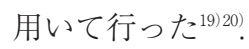

(1) 対象者

GI 測定と同様の対象者 36 名とした.

(2) 測定装置

近赤外血糖測定装置は，先行報告より ${ }^{202121) ， イ ン タ ラ ク タ ~}$ ンス方式の既存装置を基に血糖測定用に改良した装置を用 いた（図 1)。手の平が接触する測定プローブ裏面にラバー ヒーターを内蔵し, 測定プローブの温度を $36.0 \pm 0.1^{\circ} \mathrm{C}$ に保 持した，また，測定位置を一定にするために対象者（個人 用）の石亮手形を作成し，測定時にスペクトル測定部へ設 


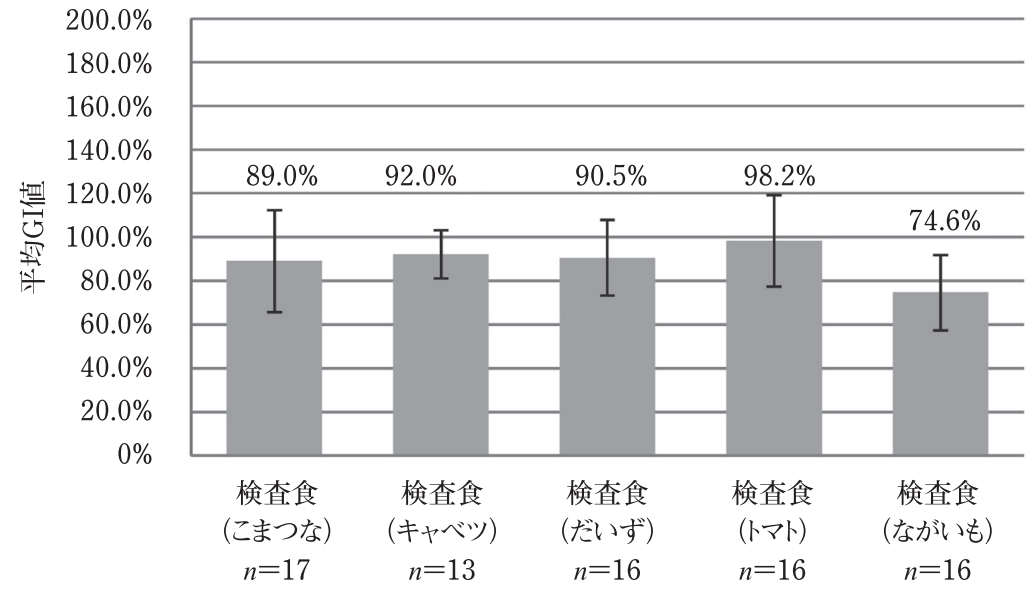

図 2 検査食品の GI に及ぼす影響

GI 測定に用いた検査食 5 種類の平均 GI 值を示した図。全ての検査食において, 平均 GI が 100 以下となった.

置した。

(3) 測定方法

測定は，前述の GI 測定における負荷試験中の SMBG と 同様のタイミングで行い, SMBG 後, 直ちに装置に設置し た石膏手形へ手の平をセットし，小指球部の近赤外拡散反 射スペクトル（700〜1050 nm）を測定した.

(4) 解析方法

より多くのデータを用いて解析することに重点を置き, 解析で用いるデータは前述の（3）GI 測定方法で示したよ うなデータの採用条件を設けず, GI 測定で得た全てのデー タで行った。各負荷試験において, 空腹時からの血糖值変 化量 $\left(\Delta B G_{t}, \mathrm{t}=0,15,30,45,60,90,120\right)$ および，空腹時か らの波長入に拈ける 2 次微分吸光度変化量 $\left(\Delta I_{\lambda t}\right)$ から, 両 者の相関係数 $\mathrm{r}_{\lambda}$ を計算し, 相関係数が最大となる波長を $\lambda^{*}$ とした，更に，目的変数を血糖值変化量 $\left(\Delta B G_{t}\right)$, 説明変 数を波長 $\lambda^{*}$ における吸光度変化量 $\left(\Delta I_{\lambda^{*} t}\right)$ として単回帰分 析を行い $\left(\Delta B G_{t}=\mathrm{a} \cdot \Delta I_{\lambda^{*} t}+\mathrm{b} \rightarrow \mathrm{a}\right.$ および $\mathrm{b}$ を推定 $)$, 吸光 度変化量 $\left(\Delta I_{\lambda^{*} t}\right)$ から血糖推定值を得た。また，血糖推定 值と SMBG による血糖実測值を用いて IAUC および GI を算出した。

\section{実験結果および考察}

\section{GI 測定}

GI 測定に用いた検査食 5 種類全てにおいて，平均 GI は 100 以下となり，基準食よりも摂取後 2 時間の血糖上昇を 抑える傾向があることを確認した（図 2)。また，試験食 摂取後 2 時間の最高血糖值を平均值で比較すると, 基準食 に対し，キャベッ，ながいもの検査食は有意 $(p<0.05)$ に 低值を示し, 特にながいもで顕著 $(p<0.001)$ であった（表 4). また, 摂取後 2 時間の IAUC を基準食と比較すると, こまつな, だいず, ながいもの検査食で有意に低值を示し, 特にこまつな，ながいもで顕著であった（図 3).
表 4 GI 測定 2 時間における基準食および検査食捸取後の 最高血糖値

\begin{tabular}{|c|c|c|c|c|}
\hline & $n$ & $\begin{array}{c}\text { 平均最高血糖値 } \\
(\mathrm{mg} / \mathrm{dL}) \text { mean } \pm \mathrm{SD}\end{array}$ & $\begin{array}{l}\text { 最大值 } \\
(\mathrm{mg} / \mathrm{dL})\end{array}$ & $\begin{array}{c}\text { 最小值 } \\
(\mathrm{mg} / \mathrm{dL})\end{array}$ \\
\hline 基準食 & 17 & $139 \pm 15$ & 172 & 113 \\
\hline $\begin{array}{c}\text { 検査食 } \\
\text { (こまつな) }\end{array}$ & 17 & $136 \pm 14$ & 172 & 114 \\
\hline 基準食 & 13 & $148 \pm 15$ & 175 & 120 \\
\hline $\begin{array}{c}\text { 検査食 } \\
\text { (キャベッ) }\end{array}$ & 13 & $142 \pm 15^{*}$ & 172 & 117 \\
\hline 基準食 & 16 & $138 \pm 14$ & 172 & 113 \\
\hline $\begin{array}{l}\text { 検査食 } \\
\text { (だいず) }\end{array}$ & 16 & $136 \pm 13$ & 173 & 107 \\
\hline 基準食 & 16 & $145 \pm 16$ & 175 & 119 \\
\hline $\begin{array}{l}\text { 検査食 } \\
\text { (トマト) }\end{array}$ & 16 & $145 \pm 14$ & 167 & 109 \\
\hline 基準食 & 16 & $141 \pm 17$ & 175 & 113 \\
\hline $\begin{array}{c}\text { 検査食 } \\
\text { (ながいも) }\end{array}$ & 16 & $124 \pm 14^{* * * *}$ & 153 & 97 \\
\hline
\end{tabular}

以上より，糖質を一定量に統一した試験食において，米 飯を主食として副菜（検査食品）一品を組み合わせること で，検査食品によっては米飯単品よりも食後血糖上昇を抑 える効果があることが明らかとなった。この要因として は，検査食品中の食物繊維の胃排出遅延および拡散阻害に よる腸管での吸収遅延 ${ }^{22)}$ や糖質消化酵素活性阻害作用 ${ }^{23}$ が，糖質の消化・吸収を抑制したものと考えられた。しか しながら，基準食と比較して摂取後 2 時間の血糖值のピー クおよびIAUC が顕著に低值であったながいもは他の検 査食品に比べてその食物繊維含有量は少なく（五訂増補日 本食品標準成分表), 上述の食物繊維による食後血糖上昇 抑制作用は小さいと考えられた。一方で，先行研究より粘 性をもつ食品は胃からの排出を遅らせ，血糖上昇を抑制す 


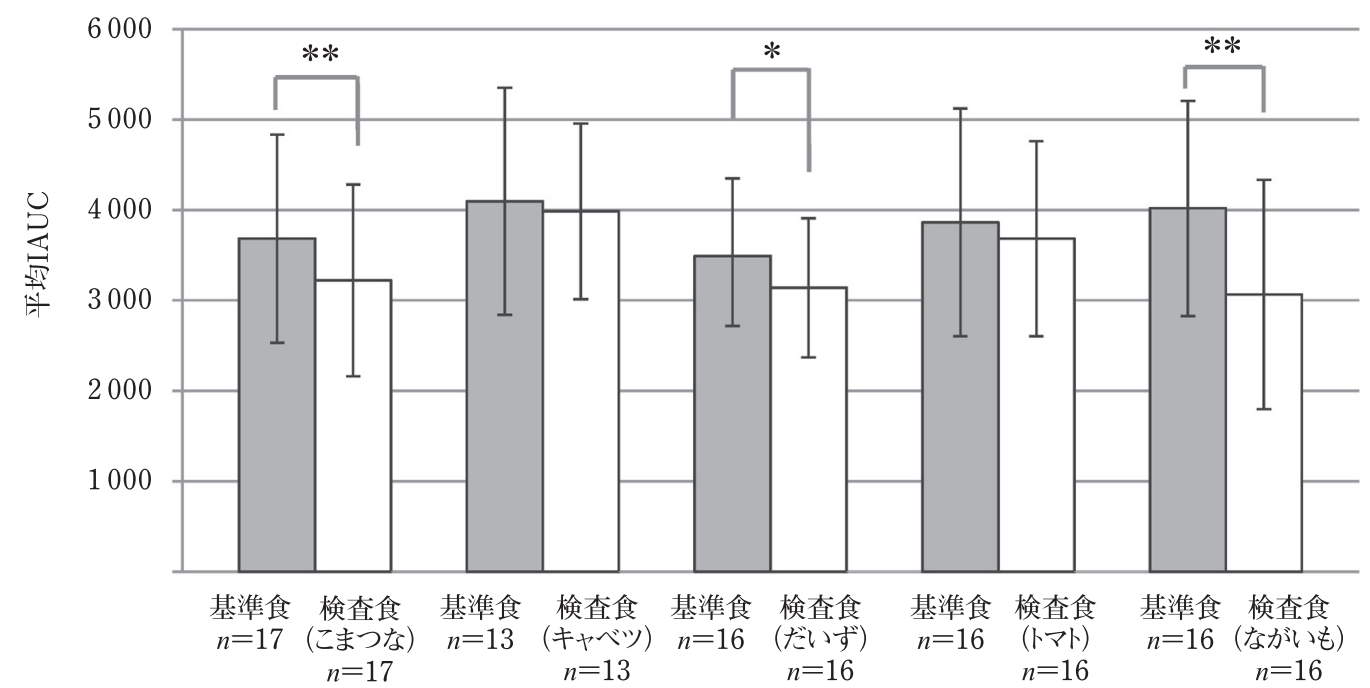

図 3 基準食および検査食摂取後の 2 時間の血糖曲線下面積

${ }^{*}, p<0.05 ;{ }^{* *}, p<0.01$ (paired t-test).

試験食摂取後 2 時間の平均 IAUC について図に示した。基準食と比較すると，こまつな，だいず，

ながいもの検査食で有意に低值を示し，特にこまつな，ながいもの検査食で有意に低值となった，

表 5 検査食品中の総ポリフェノール含量*

\begin{tabular}{ccc}
\hline \hline 試料名 & $\begin{array}{c}\text { 総ポリフェノール } \\
(\mathrm{mg} / \mathrm{dry} \cdot \mathrm{g})[\mathrm{mean} \pm \mathrm{SD}]\end{array}$ & $\begin{array}{c}\text { 総ポリフェノール }(\mathrm{mg}) \\
{\left[\begin{array}{l}\text { [対象者摂取量換算 }]\end{array}\right.}\end{array}$ \\
\hline こまつな & $8.7 \pm 0.22$ & 68.1 \\
キャベツ & $9.8 \pm 0.08$ & 57.3 \\
だいず & $2.5 \pm 0.09$ & 45.5 \\
トマト & $9.9 \pm 0.39$ & 88.7 \\
ながいも & $3.3 \pm 0.07$ & 47.8 \\
\hline
\end{tabular}

*クロロゲン酸当量として算出

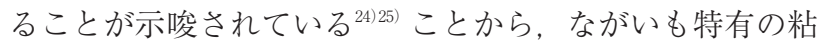
性物質であるマンナンによる吸収遅延作用が，食後血糖上 昇抑制に大きく関与したと推察された。

\section{2. 検査食品の成分分析}

食後血糖制御に関与することが示唆される総ポリフェ ノール量と食物繊維量 ${ }^{26}$ 27) について, 検査食品 5 種類の含 有量を分析した.

表 5 は検査食品中の総ポリフェノール含量を対象者摂取 量換算で示しており，トマト>こまつな>キャベッ>なが いも>だいずの順に多く含まれていた。また，表 6 は副菜 中の水溶性食物繊維，不溶性食物繊維，食物繊維総量を同 じく対象者摂取量換算值で示したものである。食物繊維含 量は何れも五訂増補日本食品標準成分表と同程度であっ た。これらの各成分含量と GI の関連について解析した が，有意な相関は認められなかった。

先行研究より, クロロゲン酸では糖質消化酵素である $\alpha$-グルコシダーゼ活性阻害作用が認められている26. ま た，食物繊維は糖質の消化・吸収を抑制することにより食 後血糖上昇を抑制することが知られており，特に水溶性食
表 6 検査食品中の食物繊維含量*

\begin{tabular}{cccc}
\hline \hline 試料名 & 水溶性食物瀻維 & 不溶性食物繊維 & 食物繊維総量 \\
\hline こまつな & 0.9 & 2.0 & 2.9 \\
キャベッ & 0.6 & 1.2 & 1.7 \\
だいず & 0.1 & 1.2 & 1.3 \\
トマト & 0.4 & 1.0 & 1.4 \\
ながいも & 0.3 & 0.8 & 1.1 \\
\hline
\end{tabular}

*対象者摂取量換算 $(\mathrm{g})$

物纎維は，水分を含むことで粘性が生じ，胃排出や小腸で の吸収を遅延させ，血糖反応を穏やかにすることが知られ ている27. 本研究では, 総ポリフェノール量および食物繊 維量と GI との間に有意な関連は認められなかったため, 検査食品中のその他の成分や糖質構成による影響が複合的 に作用したものと考えられた。

\section{3. 近赤外分光法を用いた非侵襲血糖測定法の検討}

全負荷試験の約 $95 \%$ において, 波長 $\lambda^{*}$ における吸光度 変化量と血糖変化量の相関係数 $r_{\lambda}$ * 0.6 以上であった $(0.7$ 以上：約 $84 \%$, 0.8 以上：約 $65 \%)$. 波長 $\lambda^{*}$ は個人間 や，同一個人の測定日間でも全波長領域に渡り変動した。 $\lambda^{*}$ は糖の吸収だけでなく，代謝成分に由来する可能性も高 く，このためブドウ糖の吸収バンド近傍に限らず，寄与す る波長が変動すると考えられた。血糖変化量と吸光度変化 量の相関に関する詳しい情報や波長 $\lambda^{*}$ の度数分布は先行 文献 ${ }^{28)}$ に記載されている. SMBG による血糖実測值と非 侵襲血糖測定による血糖推定值に基づくIAUC および GI を算出し各々を比較すると，共に実測值と推定值は高い相 関を示し (図 4,5), 各検査食の平均 GI の推定誤差は 1.2 以下と非常に小さいことを確認した (表 7). 尚, 結果およ 


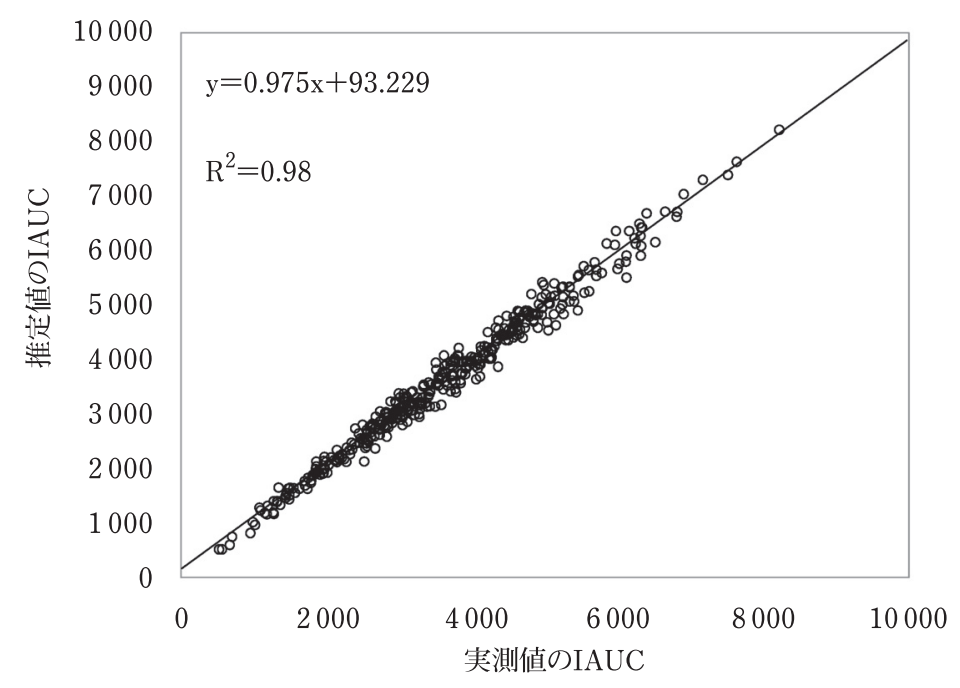

図 4 実測値と推定値に基づく IAUC の散布図

各対象者の SMBG の血糖実測值と非侵襲血糖測定の血糖推定值に基づくIAUC をプロットした図. 推定值の IAUC と実測值の IAUC は高い相関を示した.

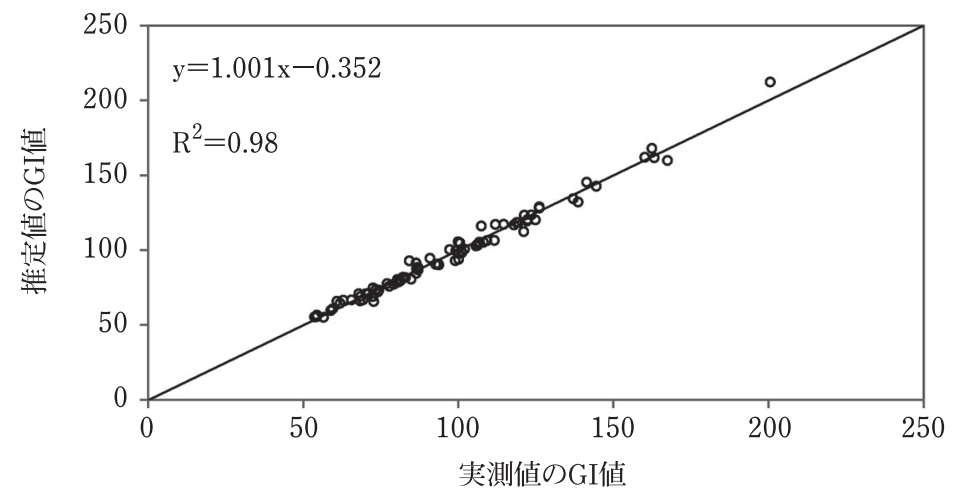

図 5 実測値と推定値に基づく GI 值の散布図

各対象者の SMBG の血糖実測值と非侵襲血糖測定の血糖推定值に基づくGI 值をプロットした図. 推定値の GI 值と実測值の GI 值は高い相関を示した

び考察の（1）GI 測定で示した平均 GI 值（図 2）と表 7 の 平均 GI 值（実測值）との相違は, 実験方法に示した様に, 両者で平均 GI 值算出に用いたデータが異なるためである.

波長 $\lambda^{*}$ が負荷試験ごとに変動することは，汎用性の高 い検量モデルを構築する上で障壁となるが，単回帰分析に より個人の検量モデルを測定日ごとに構築する手法は, 例 えば, 7 点よりも少ないデー夕数で検量モデルを作成し, 残りの時点の血糖值を吸光度から推定することで, 負荷試 験中の採血回数を低減するといった展開が可能である。今 後, 検量モデル構築時に用いる血糖実測值の最小サンプル 数や有効測定時間の延長を検討することにより， GI 測定 だけでなく糖尿病患者における血糖連続モニタリングへの 応用が期待される。

\section{要 約}

（1）日本食の主食である米飯との組合せにより，GI を低
表 7 各検査食の平均 $\mathrm{GI}$

\begin{tabular}{crcc}
\hline \hline 検査食 & $\begin{array}{c}\text { 平均 GI 值 } \\
\text { (実測値) }\end{array}$ & $\begin{array}{c}\text { 平均 GI 值 } \\
\text { (予測値) }\end{array}$ & $\begin{array}{c}\text { 誤差 } \\
\text { (実測値-予測值) }\end{array}$ \\
\hline 米飯+こまつな & 99.2 & 98.4 & 0.8 \\
米飯+キャべツ & 100.9 & 99.7 & 1.2 \\
米飯+だいず & 99.2 & 99.1 & 0.1 \\
米飯+トマト & 108.4 & 109.1 & -0.7 \\
米飯+ながいも & 78.1 & 78.3 & -0.2 \\
\hline
\end{tabular}

下させるような副菜の検討を行った。副菜である検査食品 は植物性食品 5 種類（こまつな，キャベッ，トマト，だい ず，ながいも）を供試し，全てにおいて平均 GI は 100 以下 となった，特にながいもの検査食では，基準食に比べ摂取 開始 2 時間の最高血糖值, 血糖上昇曲線下面積 (IAUC) 共 に顕著に低值を示した。これについて，ながいもの粘性物 質マンナンが胃からの排出を遅延させ，食後血糖上昇抑制 
に関与したものと推察された。

（2）検査食品中の成分と GI 低下との関連を検討するた め, 総ポリフェノール量と食物繊維量を分析した。これら の成分含量と GI との間に有意な相関は認められず，検査 食品中のその他の成分や糖質構成による影響が複合的に作

用したものと考えられた。

（3）GI 測定に応用可能な非侵襲血糖測定法の確立を目指 し，負荷試験中の SMBG と近赤外スペクトルの相関につ いて検討した。血糖值変化量と吸光度変化量の相関係数が 0.6 以上となる波長は約 $95 \%$ の負荷試験において確認され た，波長は負荷試験ごとに変動するものの，単回帰分析に より算出した推定血糖変化量から求めた IAUC および GI は，SMBGによる血糖実測值に基づく結果を良く再現して いた。

\section{文献}

1) Qiao, Q., Hu, G., Tuomilehto, J., et al., Age and sex specific prevalence of diabetes and impaired glucose regulation in 11 Asian cohorts. Diabetes Care, 26, 1770-1780 (2003).

2) DECODE Study Group., Glucose tolerance and cardiovascular mortality : comparison of fasting and 2-hour diagnostic criteria. Arch. Intern. Med., 161, 397-405 (2001).

3) Nakagami, T., Qiao, Q., Tuomilehto, J., et al., Scre-en-detected diabetes, hypertension and hypercho-lesterolemia as predictors of cardiovascular mor-tality in five population of Asian origin : the DECODA study. Eur. J. Cardiovasc. Prev. Rehabil., 13, 555-561 (2006).

4) Levian, E.B., Song, Y., Ford, E.S., et al., Is non-diabetic hyperglycemia a risk factor for cardio-vascular disease? A metaanalysis of prospective studies. Arch. Intern. Med., 164 2147-2155 (2004)

5) Salmeron, J., Ascherio, A., Rimm, E. B., Colditz, G. A., Spiegelman, D., Jenkins, D.J., Stampfer, M.J., Wing, A.L. and Willett, W. C., Dietary fiber, glycemic Ioad, and risk of NIDDM in men. Diabetes Care, 20, 545-550 (1997).

6) International Diabetes Federation : Guideline for management of postmeal glucose. (2007).

7) Jenkins, D.J., Wolever, T.M., Taylor, R.H. and Barker, H., Glycemic index of foods : a physiological basis for carbohydrate exchange. Am. J. Clin. Nutr., 34, 362-366 (1981).

8）厚生労働省: 平成 25 年国民健康·栄養調査 (生活習慣調査), http://www.mhlw.go.jp/bunya/kenkou/eiyou/dl/h25-houkoku06.pdf, (2015. 2. 16)

9）杉山みち子, 若木陽子, 中本典子, 小山和作, 他：ごはん食 と Glycemic Index に関する研究. 日本健康・栄養システム 学会誌, 3, 1-15 (2003)

10） Robinson, M.R. and Eaton, R.P., Haaland D.M., Koepp, G.W., Thomas, E.V., Stallard, B.R. and Robinson, P.L., Noninvasive glucose monitoring in diabetic patients : a preliminary evaluation. Clin. Chem., 38, 1618-1622 (1992).

11) Fischbacher, Ch., Jagemann, K.-U., Danzer, K., Müller, U.A., Papenkordt, L. and Schüler, J., Enhancing calibration models for non-invasive near-infrared spectroscopical blood glucose determination. Fresen. J. Anal. Chem., 359, 78-82 (1997)

12) Sämann, A., Fischbacher, Ch., Jagemann, K.-U.,Danzer, K., Schüler, J., Papenkordt, L. and Müller, U.A., Non-invasive blood glucose monitoring bymeans of near infrared spectroscopy : investiga-tion of long-term accuracy and stability. Exp. Clin. Endocr. Diab., 108, 406-413 (2000).

13) Uwadaira, Y., Shimotori, A., Ikehata, A., Fujie, K., Nakata, Y., Suzuki, H., Shimano, H. and Hashimoto, K., Logistic regression analysis for identifying the factors affecting development of non-invasive blood glucose calibration model by near-infrared spectroscopy. Chemometr. Intell. Lab. Syst., $148,128-133$ (2015).

14）糖尿病食事療法のための食品交換表 第 7 版。（日本糖尿病 学会 編著)，p. 58，文光堂，東京 (2004).

15）四群点数法のすべて 4 つの食品群でバランス栄養食.（香 川 綾，香川芳子 監修)，p. 161，女子栄養大学出版部，東 京 (1993).

16）食品成分表 2015 資料編．（香川芳子 監修），p. 84，女子栄 養大学出版部, 東京 (2015).

17）厚生労働省・農林水産省決定 食事バランスガイドーフード ガイド（仮称）検討会報告書一(第一出版編集部編集), p. 11，第一出版，東京 (2006).

18）津志田藤二郎，鈴木雅博，黒木柾吉： : 各種野菜類の抗酸化 性の評価および数種の抗酸化成分の同定.41，611-618 (1994).

19) Golic, M., Walsh, K. and Lawson, P., Short-wave-length nearinfrared spectra of sucrose, glucose, and fructose with respect to sugar concentration and temperature. Appl. Spectrosc., 57, 139-145 (2003).

20) Uwadaira, Y., Adachi, N., Ikehata, A. and Kawano, S., Factors afecting the accuracy of non-invasiveblood glucose measurement by short wavelength n-ear infrared spectroscopy in the determination ofthe glycaemic index of foods. J. Near Infrared Spe-ctrosc., 18, 291-300 (2010).

21）上平安紘，足立憲彦，池羽田晶文，河野 澄，短波長域を用 いた近赤外分光法による非侵襲血糖值測定装置の開発とそ の応用，日本食品科学工学会誌，58，97-104 (2011).

22) Jenkins, D.J.A., Wolever, T.M.S., Jenkins, A.L. and Taylor, R.H., Dietary fibre, carbohydrate metabolism and diabetes. Molecular Aspects of Medicine, 9, 97-112 (1987).

23) Ou, S., Kwok, K.-C., Li, Y. and Fu, L., In vitro study of possible role of dietary fiber in lowering postprandial serum glucose. J. Agric. Food Chem., 49, 1026-1029 (2001).

24) Wolf, B.W., Wolever, T.M., Lai, C.S., et al., Effects of a beverage containing an fiber, with or without fructose, on the postprandial glycemic response to a high glycemic index food in humans. Eur. J. Clin. Nutr., 57, 1120-1127 (2003).

25) Sanggaard, K.M., Holst, J.J., Rehfeld, J.F., et al., Different effects of whole milk and a fermented milk with the same fat and lactose content on gastric emptying and postprandial lipaemia, but not on glycemic response and appetite. $\mathrm{Br}$. J. Nutr., 92, 447-459 (2004).

26）立石絵美，韓 立坤，奥田拓道：ラットに扔ける食後の血糖 值に及ぼすコーヒー豆の熱水抽出物の影響。栄養学雑誌, 62, 323-327 (2004).

27) Jenkins, D.J., Wolever, T., Ocana, A.M., et al., Dietary fibers, fibre analoges, and glucose tolerance: important of viscosity. Br. Med. J., 27, 1392-1394 (1978).

28) Uwadaira, Y., Ikehata, A., Momose, A. and Miura, M., Identification of informative bands in the short-wavelength NIR region for non-invasive blood glucose measurement. Biomed. Opt. Express, 7, 2729-2737 (2016).

(平成 27 年 12 月 4 日受付, 平成 28 年 7 月 27 日受理) 